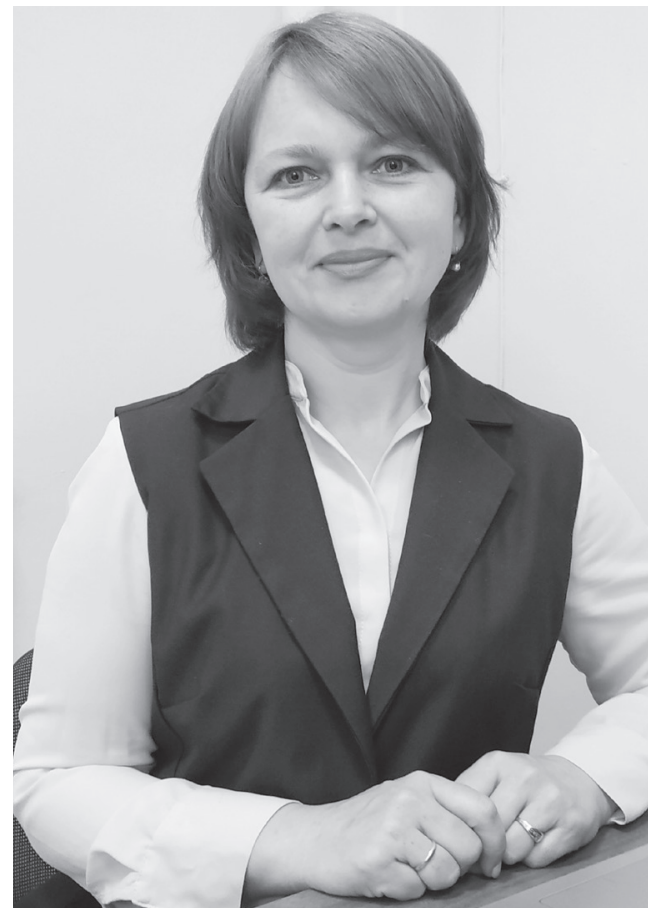

UDC: 351: 37.07

DOI: https://doi.org/10.32689/2617-

2224-2019-4(19)-174-188

Moroz Svitlana Anatoliyona,

Candidate of Science in Public Administration, Senior Research Officer of Training Research and Production Center, National University of Civil Protection of Ukraine, 61023, Kharkiv, Str. Chernyshevska, 94, tel.: (095) 507-14-35, e-mail: ra.ekma@gmail.com

ORCID: 0000-0002-2696-1278

Мороз Світлана Анатоліївна, кандидат наук з державного управління, старший науковий співробітник Навчально-науково-виробничого центру, Національний університет иивільного захисту України, 61023, м. Харків, вул. Чернишевська, 94, тел.: (095) 507-14-35, e-mail:ra.ekma@gmail.com

ORCID: 0000-0002-2696-1278

Мороз Светлана Анатольевна, кандидат наук по государственному управлению, старший научный сотрудник Учебно-научно-производственнного центра, Национальный университет гражданской защиты Украины, 61023, г. Харьков, ул. Чернышевская, 94, тел.: (095) 507-14-35, е-таіl: ra.ekma@gmail.com

ORCID: 0000-0002-2696-1278

\title{
EVALUATION OF THE QUALITY OF HIGHER EDUCATION BY CHINESE STUDENTS AS THE BASIS FOR THE USAGE OF ITS EXPERIENCE IN IMPROVING SYSTEMS OF MANAGEMENT OF THE EDUCATIONAL SPHERE OF UKRAINE
}

Abstract. Problem setting. Clarification of the directions and conditions of effective reform of the higher education system of Ukraine, taking into account its considerable importance in ensuring the socio-political and socio-economic development of Ukraine, is an important way of organization a scientific research. Within the framework of the relevant problematics among the possible scientific tasks, including those content of which is associated with the identification of the features of the functioning of foreign models of the higher education system de- 
velopment and determining the level of satisfaction of objects of educational communication with the quality of educational services.

Paper objective. To hold an analysis of thoughts of Chinese students as for quality of higher education on the University and State levels, and also determine those directions of country's politics which at the time ensured the dynamics of growth in the quality of functioning of the higher education system in China.

Paper main body. Basing on the results of analysis of international world ranking Quacquarelli Symonds there was determined that temps of increasing of quality of higher education system of China are much higher comparing to the temps which are demonstrated by the systems of higher education of other countries of the. With the aim to determine the peculiarities of perception of the phenomenon of the higher education with Chinese students, authors of this article maid a survey of students of the Institute of International and Comparative Education at Beijing Normal University (China). Basing on the analysis of the results of the answers such facts were determined: the indicators of assessment of the quality of higher education in China and a particular University are not identical; the vast majority of Chinese students not only assess the quality of higher education at a high level, but also are satisfied with its indicators (compliance of the quality of higher education with the requirements of the labour market); the opinion of students should be taken into account by the subjects of public administration during the national monitoring of the quality of higher education.

Conclusions of the research. The state policy of Ukraine as for ensuring the quality of higher education should be developed taking into account the world's best models of higher education. In this context, we propose to create and implement programs such as Chinese Projects 211 (selection of the 100 best Universities of higher education of China for the implementation of the state order for the training of highly qualified specialists) and 985 (ensuring the positioning of the best universities in China at the level of leading Higher education universities within the international University rankings).

Keywords: quality of higher education, the system of higher education, Chinese students, survey, subjects of public administration, state politics.

\section{ОЦІНЮВАННЯ ЯКОСТІ ВИЩОЇ ОСВІТИ СТУДЕНТАМИ З КИТАЮ ЯК ПІДГРУНТЯ ДЛЯ ВИКОРИСТАННЯ ЙОГО ДОСВІДУ У ВДОСКОНАЛЕННІ СИСТЕМИ УПРАВЛІННЯ ОСВІТЯНСЬКОЮ ГАЛУЗЗЮ УКРАЇНИ}

Анотація. 3'ясування напрямів та умов ефективного реформування системи вищої освіти України, з огляду на неабияку її значущість у забезпеченні суспільно-політичного та соціально-економічного розвитку України, є актуальним напрямом в організації наукових пошуків. Серед можливих наукових завдань, у межах відповідної проблематики, є у тому числі й ті, зміст яких пов’язано з виявленням особливостей функціонування зарубіжних моделей 
розбудови системи вищої освіти та з'ясування рівня задоволеності об'єктів навчальної комунікації якістю надання освітніх послуг.

Проаналізовано думки студентів з Китаю щодо якості вищої освіти на університетському та державному рівнях, а також виявлено ті з напрямів державної політики, які свого часу забезпечили динаміку зростання якості функціонування системи вищої освіти Китаю.

За результатами аналізу міжнародного рейтингу Quacquarelli Symonds встановлено той факт, що темпи зростання якості системи вищої освіти Китаю є значно вищими порівняно з тими темпами, які демонструють системи вищої освіти інших країн світу. 3 метою з'ясування особливостей сприйняття феномену якості вищої освіти китайськими студентами, авторами цієї публікації було проведено опитування студентів Institute of International and Comparative Education at Beijing Normal University (China). За результатами аналізу відповідей студентів встановлено такі факти: показники рівня оцінки якості вищої освіти в Китаї та конкретному університеті не є ідентичними; переважна більшість китайських студентів не лише оцінює якість вищої освіти на високому рівні, а й є задоволеною його показниками (відповідність якості вищої освіти вимогам ринку праці); думка студентів має враховуватись суб'єктами державного управління під час проведення загальнонаціонального моніторингу якості вищої освіти.

Державна політика України щодо забезпечення якості вищої освіти повинна розбудовуватись 3 прийняттям до уваги кращих світових моделей системи вищої освіти. В цьому контексті пропонуємо скласти та забезпечити реалізацію програм на кшталт китайських Проектів 211 (вибір 100 найкращих 3ВО Китаю для реалізації державного замовлення на підготовку висококласних фахівців) та 985 (забезпечення позиціонування кращих університетів Китаю на рівні ЗВО-лідерів у межах міжнародних університетських рейтингів).

Ключові слова: якість вищої освіти, система вищої освіти, китайські студенти, опитування, суб'єкти державного управління, державна політика.

\section{ОЦЕНКА КАЧЕСТВА ВЫСШЕГО ОБРАЗОВАНИЯ СТУДЕНТАМИ ИЗ КИТАЯ КАК ОСНОВА ДЛЯ ИСПОЛЬЗОВАНИЯ ЕГО ОПЫТА В УСОВЕРШЕНСТВОВАНИИ СИСТЕМЫ УПРАВЛЕНИЯ ОБРАЗОВАТЕЛЬНОЙ ОТРАСЛЬЮ УКРАИНЫ}

Аннотация. Выяснение направлений и условий эффективного реформирования системы высшего образования Украины, учитывая ее большую значимость в обеспечении общественно-политического и социально-экономического развития Украины, является актуальным направлением в организации научных исследований. Среди научных задач, в пределах соответствующей проблематики, позиционируют в том числе и те, содержание которых связано с выявлением особенностей функционирования зарубежных моделей развития системы высшего образования, а также определением уровня удовлетворенности объектов учебной коммуникации качеством предоставления образовательных услуг. 
Проанализировано мнение студентов из Китая относительно качества высшего образования на университетском и государственном уровнях, а также выявлены те из направлений государственной политики, которые в свое время смогли обеспечить динамику улучшения качества функционирования системы высшего образования Китая.

По результатам анализа международного рейтинга Quacquarelli Symonds установлено тот факт, что темпы улучшения качества системы высшего образования Китая значительно выше по сравнению с теми темпами, которые демонстрируют системы высшего образования других стран мира. С целью выяснения особенностей восприятия китайскими студентами феномена качества высшего образования, авторами этой публикации был проведен опрос студентов Institute of International and Comparative Education at Beijing Normal University (China). По результатам анализа ответов студентов установлены следующие факты: показатели уровня оценки качества высшего образования в Китае и конкретном университете не являются идентичными; подавляющее большинство китайских студентов не только оценивает качество высшего образования на высоком уровне, но и удовлетворена его показателями (соответствие качества высшего образования требованиям рынка труда); мнение студентов должно учитываться субъектами государственного управления во время проведения общенационального мониторинга качества высшего образования.

Государственная политика Украины по обеспечению качества высшего образования должна формироваться с принятием во внимание лучших зарубежных моделей системы высшего образования. В этом контексте предлагаем составить и обеспечить реализацию программ наподобие китайских проектов 211 (выбор 100 лучших ВУЗов Китая для реализации государственного заказа на подготовку высококлассных специалистов) и 985 (обеспечение позиционирования лучших университетов Китая на уровне ВУЗовлидеров в рамках международных университетских рейтингов).

Ключевые слова: качество высшего образования, система высшего образования, китайские студенты, опрос, субъекты государственного управления, государственная политика.

Statement of problem in general and its connection with important scientific or practical tasks. The problems of higher education quality, considering its considerable significance for ensuring social and political, social and economic development of the state, is constantly within the sphere of scientific attention of researchers and focus of professional activity of the specialized state administration authorities. The fact of growth of the number of scientific and communicative measures of the relevant content indicates the attention of scientists to solving the issues of improving the existing mechanisms of the state administration of education sector. For example, over 
the past year more than 10 scientific and practical conferences were held, the most interesting of which are: AllUkrainian scientific and methodical conference "Modernization of higher education and problem of quality control of training of specialists. Organization of the interaction system "Higher education - labor market" (28.09.2018, Kharkiv - Kharkiv State University of Food Technology and Trade); International scientific and practical conference "Quality of higher education: Ukrainian national system and European practices" (6-7.12.2018, Kyiv Taras Shevchenko National University of Kyiv); International scientific and practical conference "Administration in Education" (04-05.04.2019, Lviv Lviv Polytechnic National University). The importance of issues of higher education quality for further development of the state is indicated by the fact of their positioning at the priority level within the framework of international, state and regional program documents (Sustainable Development Goals 20162030 (UN), Association Agreement between Ukraine and the European Union (Verkhovna Rada of Ukraine); Strategy for Sustainable Development "Ukraine 2020" (President of Ukraine); Government's Medium-Term Priority Action Plan to 2020 (Cabinet of Ministers of Ukraine); Priority Areas for Changes in Higher Education for 20182019 (Ministry of Education and Science of Ukraine), etc.).

The issue of quality assurance in higher education, along with integration into the European space of higher education and scientific research and lifelong learning, was determined by the Ministry of Education and Science of Ukraine at the level of one of the priority directions of change in higher education for 2018-2019 [1]. Taking into account the above, we can state that the subjective and objective orientation chosen by us in the organization of scientific research is relevant and practically significant.

The effective solutions of the issue of quality assurance in higher education can be searched by several rather independent directions, for example: theoretical and methodological substantiation of the content of subject of scientific attention and determination of conditions for its effective development; substantiation of the competence of the state and society institutions and university institution; study of foreign models of quality assurance in higher education, etc. Each of these directions, in this or that volume of their scientific study, developed within the preliminary studies of domestic and foreign scientists.

Analysis of recent researches and publications, in which the solution of this problem was initiated and which the author relies on. The problems of quality assurance in higher education were positioned within the focus of scientific attention of S. K. Andreichuk, L. I. Antoshkina, A. V. Verbytska, L. A. Haievska, L. V. Holovii, S. M. Dombrovska, D. I. Dzvinchuk, M. I. Dudka, Yu. O. Zhuravliova, V. S. Zhuravskyi, S. A. Kalashnikova, V. H. Kremen, V. I. Luhovyi, V. M. Moroz, O. V. Postupna, T. Yu. Skyba and other researchers. The issues of education management have developed in the research of Ralph Lewis and Douglas Smith (analysis of the system of quality management in higher education, as well as 
substantiation of the program content for its improvement at the university level [2]), Ronald Barnett (principles of effective functioning of the system of quality assurance in higher education are determined [3]), Mohammad Ouli (main characteristics of higher education quality are determined and the criteria for its assessment are substantiated; place and role of public administration authorities in the system of quality assurance in higher education are considered [4], Claire Chuai (integrated approach to formation of the system of higher education quality is proposed; main characteristics of higher education are determined [5]), Diana Green, William Stubbs, Pauline Perry, Jim Finch, Jan Riesbeck [6] and other scientists. We considered some issues of the problems concerned with context of solving relevant issues within the previous directions of scientific researches [7; 8]. Despite the sufficient level of scientific attention to the problems of higher education quality, process management and technology of its assurance, some of its directions are still open for further scientific research.

Allocation of previously unsolved parts of the general problem to which this article is devoted. The great majority of scientific researches on the problems of higher education quality are purely theoretical. Certainly, solving problems of scientific and theoretical direction, as well as solving problems of methodological direction is of great importance for formation of the basis for ensuring practice of functioning of the higher education system. At the same time, imbalance between theoretical and practical researches not only increases the risk of dispropor- tion when considering the subject of scientific attention (gap between the levels of knowledge as a result of use of theoretical and practical methods of scientific knowledge may be the cause of the so-called unilateral perception of the subject of scientific attention), but also may cause distortion of the content of the subject studied. Our analysis of recent scientific researches on the problems of quality assurance in higher education shows that within the limits of national scientific idea there is a lack of those studies that helped to obtain the results due to the use by scientists of methods of empirical research, namely those that relate to methods of scientific data obtaining. Such methods usually include observation, testing, questioning, interviews, conversations, chronometry, etc. [9, p. 183]. Certainly, questioning the representatives of certain categories of so-called stakeholders (subjects and objects of educational communication; employers and other consumers of the results of educational services, etc.) are not something new for domestic scientific dispute, as questioning, for example, the students and professors of higher education institutions is rather common practice especially within context of procedures for ensuring the quality of educational activity and quality of higher education (system of internal quality assurance) by higher education institutions. At the same time, representatives of domestic higher education system become the object for organizers of questioning, and accordingly the obtained results are related exclusively to specific features of its functioning and development. Such subjective and objective orientation of using the methods of empirical kno- 
ledge defines not only the narrowing of sphere of scientific researches, which affects the quality of scientific researches by itself, but also makes it impossible to carry out the comprehensive analysis of foreign models of development as a direct system for ensuring the quality of educational activity and quality of higher education in general by higher education institutions. The difficulty of search of counteragents outside Ukraine by domestic scientists, which are interested in the relevant problems, limits the potential of studying the foreign experience to only theoretical methods. In other words, within domestic scientific idea there are almost no directions of research of features of functioning and development of foreign models of the higher education system that helped to obtain the results due to use of experimental methods of scientific knowledge. Within this publication we intend to focus our research attention on expert assessment of higher education quality by students of foreign higher education institutions both at a particular university and in country of its location. Within the previous directions of our scientific researches we showed the applicability of students' opinion at the level of expert assessment [10], and therefore consider it possible, at least within this research, to leave this issue without further substantiation.

Article objective statement (task assignment). Analysis of answers of students of higher education institutions (on the example of analysis of results of an expert questioning of students from China) on the quality of educational services, as well as substantiation of possibility to use the experience of China for improvement of content and practice of using the mechanisms of public administration of education sector.

Statement of main research material with full substantiation of the obtained scientific results. Taking into account the fact that students of any country could hypothetically become the source of information, provided that the author of this publication finds the foreign counterparts potentially interested in the issue concerned, we will try to explain our choice in favor of Chinese students.

First, our interest in China was defined by rates of prestige growth of Chinese universities within international university rankings. For example, according to results of expert assessment by experts of the British consulting company Quacquarelli Symonds (QS), within QS World University Rankings 2016 [11], only 4 Chinese universities were represented at the world's top 100 best universities. In 2019, 6 Chinese universities were ranked within the relevant rating group [12]. As a comparison, US universities, the indisputable leaders in the ranking, in 2016 ranking were presented in the top hundred in the amount of 30 higher education institutions, and in 2019 ranking 31 higher education institutions. It is obvious that China shows more powerful dynamics of increase in number of universities in the so-called TOP of corresponding ranking. Thus, the remarkable progress of Chinese higher education institutions in the authoritative university ranking caused the interest of the author of this publication to search for a counterpart from China. 
Secondly, the Chinese higher education system within QS Higher Education System Strength Rankings 2018 received the expert assessment at the $8^{\text {th }}$ position [13]. It is interesting that higher education systems of Hong Kong and Taiwan, which were developed under influence of Anglo-Saxon and Japanese traditions of education sector, were assessed at the $18^{\text {th }}$ and $19^{\text {th }}$ positions, respectively. In other words, the use of experience, which in due time ensured the leadership of universities based on its principles, is not always effective now. In turn, the experience of so-called non-classical or new models of the development of higher education system (China, South Korea), considering its potential for ensuring the growth of competitiveness of universities, is more attractive for study and further implementation of its individual practices (principles) in the domestic higher education system.

The feature of our publication is the fact that we selected the students of the Institute of International and Comparative Education at Beijing Normal University (China) as respondents. The questioning of students of this Institute became possible due to agreements between participants of the informal scientific team of domestic and foreign scientists on carrying out the out-grant (lack of any financial support from state, commercial and public institutions) research "Assessment of higher education quality". Leaving unnoticed the content and practice of implementing the mechanism of search for counterparty from China interested in the project, we will proceed directly to the presentation of the results obtained by us.
Among the issues of the questionnaire developed according to methodological advice of S. Sudman and $\mathrm{N}$. Bradburn [14] were also those the content of which was focused on assessment of quality of higher education in China and the Institute of International and Comparative Education at Beijing Normal University (IICE at BNU) by respondents. Before the questioning, the students were explained the scale of assessment of higher education phenomenon (1 point corresponds to the minimum possible, and 10 points - to the maximum possible levels of higher education quality). The obtained results are shown in Fig. 1.

According to results of the analysis of respondents' answers on the assessment of quality of higher education in China and IICE at BNU, we can state that:

- the great majority of respondents consider that the quality of higher education in China is quite satisfactory (92\% of respondents assessed the quality of higher education in the country at the level from 4 to 8 points);

- every twentieth respondent (5\% of the questioned students) assesses the quality of higher education at very high level, which taking into account the part of students who assessed the quality of higher education at high level $(62 \%)$, allows us to assume that in general the students are satisfied with the quality level of higher education offered by the state;

- $3 \%$ of respondents assessed the quality of education in China at low level (from 0 to 3 points). Of course we have to accept their opinion, but at the same time, the part of Chinese students dissatisfied with the quality of higher 
Quality level of higher education in Chine

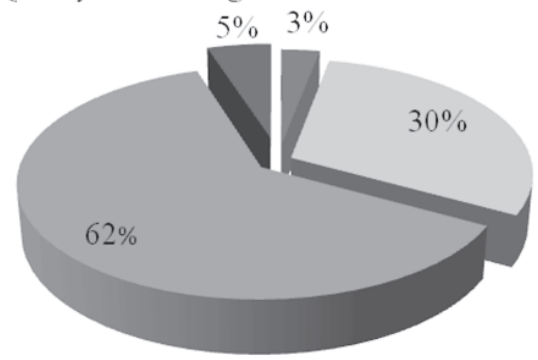

Quality level of higher education at IICE at BNU $0 \% \quad 3 \%$

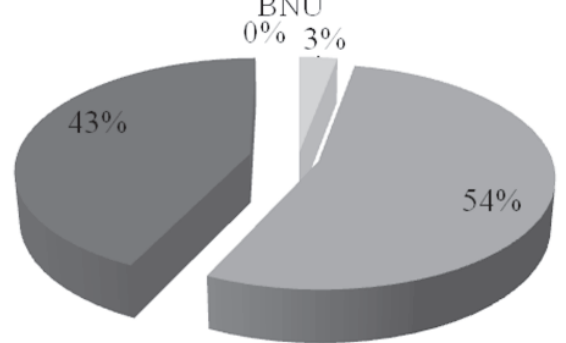

Low level (from 0 to 3 points); Sufficient level (from 4 to 6 points); High level (from 7 to 8 points); Very high level (from 9 to 10 points)

Fig. 1. Quality level of higher education

(according to results of questioning the students of IICE at BNU)

education is insignificant, and therefore we can ignore it when drawing the final conclusions. In addition, among dissatisfied students may be those who are dissatisfied due to their high level of academic training (student's academic potential is greater than possibilities offered to him by higher education system), and those who are dissatisfied due to too low level of their academic potential;

- the great majority of students is convinced that the quality of higher education in their higher education institutions is quite satisfactory (57\% of respondents assessed the quality of higher education in their higher education institutions at the level from 4 to 8 points);

- none of the respondents assessed the quality of education at their university at the level from 1 to 3 points that together with indicator from 4 to 6 points at the level of $3 \%$ almost reduces the influence of the fact of dissatisfaction. The difference between assessment of the quality of higher education in the state and specific higher education institution in the range from 1 to 6 points is quite interesting, which indicates a certain disproportion in the development of so-called capital and regional higher education institutions;

- $43 \%$ of students assessed the quality of higher education at their university from 9 to 10 points (very high) that when comparing in the corresponding range of points by assessment at the state level (43\% against $5 \%$ ) confirms our assumption on disproportions in the development of universities of China;

- percent of assessments in the plane of "low level" criterion, when comparing the state and university level, indicates that a significant part of students consider the quality of educational services provided by their university to be higher than in the country in general (30\% assessed the quality of higher education in the country at "low level" level, while the corresponding indicator at the university level is only $3 \%$ );

- percent of assessments in the plane of "very high" criterion, when comparing the state and university level, indicates that some students consider the quality of educational services provided by their university to be higher than in the country in general ( $43 \%$ assessed 
the quality of higher education in their higher education institution at "very high" level, while the corresponding indicator at the state level is only $5 \%$ ).

In the questionnaire proposed for students, the authors of the research included also questions on student satisfaction with the quality of higher education in the country of its obtainment. According to the logic of research development, in authors' opinion such question was extremely necessary, as the assessment of "quality level of higher education" and "level of satisfaction with the quality of higher education" are not identical directions when examining the subject of scientific attention. For example, person can assess the "quality level" as low, but at the same time be fully satisfied with it (this situation is hypothetically possible if the quality of educational services does not comply with requirements of the labor market, that is, the person realizes that the quality of higher education is rather low (he compares it with the quality of higher education provided by leading universities), but, at the same time, he realizes that even this level will be enough to meet the requirements of the labor market). In other words, when assessing the "quality level of higher education", the respondent is guided by a system of objective indicators, while assessing the "level of satisfaction" defines the use of subjective measurement criteria. A deeper substantiation of the difference between the above phenomena requires a separate direction of scientific research and at the same time, more likely, outside the field of knowledge of the state and administration science. Thus, we consider it possible to limit ourselves to the above thesis and proceed to the direct analysis of respondents' answers on the appropriate focus of scientific attention. The results of assessing the level of students' satisfaction with quality of higher education in China are shown in Fig. 2.

Thus, almost every second respondent (49\%) in general is satisfied with the quality level of higher education offered by higher education institutions of China. Every fifth respondent (21\%) chose the answer of higher level of satisfaction. None of the respondents agree with a statement that he is fully

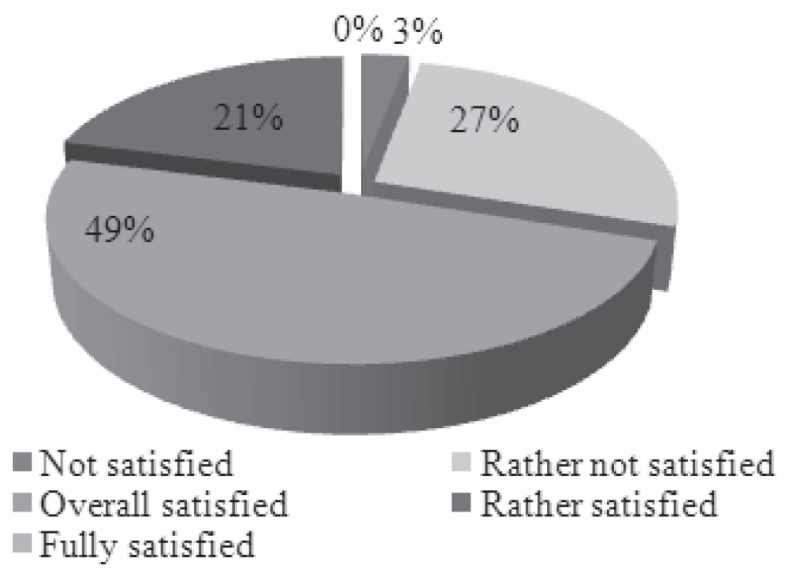

Fig. 2. The level of student satisfaction with the quality of higher education in China 
satisfied with the quality of higher education. This fact identifies the sufficient level of awareness of Chinese students on the quality of educational services in other countries of the world, as well as on certain openness of information space of China. The interesting fact for researchers was the fact that $30 \%$ of respondents are not satisfied with the quality of higher education in China. On the one hand, this fact confirms our assumption on the openness of information space of China (increase in volume of information promotes the improvement of quality of the expert opinion), and on the other hand, it indicates, on the one part, the increase in level of insistence of educational communication objects to the level proposed by the system for knowledge acquisition, and on the other part - the imperfection of the system of quality assurance in higher education of China. The last thesis, considering the debatability of its content, needs to be clarified within the further directions of scientific search.

Certainly, the carried out analysis is not complete, and therefore it can be expanded within other directions of scientific search. At the same time, the generalizations defined by us may be useful for improving the content and practice of using some mechanisms of public administration of higher education quality within domestic system of its development.

Conclusions from this research and prospects for further researches in this direction. Taking into account the foregoing, we can define the following main conclusions.

First, the reform of higher education system introduced in due time by the
Government of China ( $3^{\text {rd }}$ Plenum of the Central Committee of the Communist Party of China of $11^{\text {th }}$ convocation (18.12-22.12.1978) - introduction of reforms; $3^{\text {rd }}$ plenum of the Central Committee of the Communist Party of China of $18^{\text {th }}$ convocation (09.11.11.12.2013) - deepening of reforms) promoted the increase in level of competitiveness of its main elements. The mechanisms of reforming the sphere of higher education chosen by the subjects of public administration not only ensured the overcoming of negative consequences of the so-called Cultural Revolution in educational sphere (it is considered that the Cultural Revolution and the so-called Great Leap almost destroyed the higher education system of China), but also caused the powerful dynamics of growth of qualitative characteristics of higher education system of China to the level of indicators demonstrated by the corresponding systems of leading countries in ensuring the quality of higher education. We offer to improve the content of administrative and organizational mechanism of public administration in the sphere of higher education in the direction of programming the reforms within annual, five-year and ten-year plans for development of education sector. The content of these plans, as well as the terms of their implementation, should not depend on changing the political situation in the state.

Secondly, disproportions in development of universities are not only a source for increasing the level of competitiveness of higher education institutions, which by itself is already an important condition for improving the university's qualitative characteris- 
tics and the basis for formation of the so-called locomotive of changes in the sphere of higher education. The Project 211 (choice of 100 best higher education institutions of China for implementation of the state order for training of high-level specialists to ensure the reform of economic and social subsystems of society) and 985 (ensuring the positioning of the best universities in China at the level of leading higher education institutions within international university rankings) adopted by the Government of China, provided, on the one hand, the dynamic development of domestic universities, and on the other hand - possibility of comprehensive generalization of their experience. We offer to improve the content of normative and legal mechanism of public administration in the sphere of higher education through implementation of norms on the priority development of several domestic universities and ensuring their entry, for example, to 200 best universities in the world.

Thirdly, the Chinese model of organization of the higher education system ensures not only its quality (as confirmed by international rankings), but also the satisfaction of educational communication objects with the level of professional knowledge and skills acquired. We offer to improve the system of public control over the assurance of quality of educational services and quality of higher education by higher education institutions due to use of methods of students' questioning within its procedures. By the way, the Chinese practice of organization of monitoring the quality of higher education, at least at the university level, implies the obligatory participation of students in assess- ing the quality of discipline teaching by scientific and pedagogical staff (student cannot complete a session without filling in the questionnaire on the quality of educational process organization and quality of education material teaching). The students' questioning at university and national levels will allow the administration of higher education institutions and public administration entities to obtain information from the direct participant (object) of the educational communication on the level of his satisfaction with the quality of higher education. The obtained information can be used as one of the criteria for assessment: by state - quality of implementation by higher education institutions of the public contract for training the specialists with higher education; by society - compliance of quality of higher education with requirements (needs) of the labor market.

For the representatives of scientific community who are interested in the possibility of using the comparative method for the study of problems of quality of higher education, we suggest paying attention to the results of our analysis of the Latvian students' opinion on the above focus of scientific attention [15]. Certainly, the above conclusions do not exhaust the content of problems of student participation in monitoring the quality of higher education, and therefore can be added and specified during further scientific researches of the relevant thematic direction. In our opinion, the most relevant directions are those that are related to the definition of the effectiveness level of system for ensuring the quality of educational activity and quality of 
higher education in general by higher education institutions.

The author gratefully acknowledges the administration of the Institute of International and Comparative Education at Beijing Normal University (China) represented by prof. Liu Baocu for assistance of organization of students' questioning, and Uliana Furiv (University of Tampere, Finland) for its direct carrying out in the territory of China.

\section{REFERENCES}

1. Grinevich L. M. (2018). Prioritetni napryami zmin u vishij osviti na 20182019 rr. [Priority directions for changes in higher education in 2018-2019]. Ministerstvo osviti i nauki Ukrayini. Ministry of Education and Science of Ukraine. Retrieved from: https://mon. gov.ua/storage/app/media/vishchaosvita/infographik/MON_prioritety_ new.pdf [in Ukrainian].

2. Lewis R.G., Smith D.H. (1994). Total Quality in Higher Education. Total Quality Series. Delray Beach: St Lucie Press [in USA].

3. Barnett R. (1992) Improving Higher Education: Total Quality Care. London: Open University Press [in United Kingdom].

4. Owlia M. S. \& Aspinwall E. M. (1996). A framework for the dimensions of quality in higher education. Quality Assurance in Education, 4, 12-20 [in USA].

5. ChuaC. (2004). Perception of Quality in Higher Education. AUQA Occasional Publication: Proceedings of the Australian Universities Quality Forum 2004. Retrieved from: http://citeseerx. ist.psu.edu/viewdoc/download?doi= 10.1.1.125.3578\&rep=rep1\&type $=$ pdf [in Australia].
6. Green D., William H. S., Perry P. (1994) What Is Quality in Higher Education? London: Society for Research into Higher Education \& Open University Press [in United Kingdom].

7. Moroz S. A., Moroz V. M. (2015). Struktura vysshego uchebnogo zavedenija kak obekt gosudarstvennogo upravlenija [The structure of a higher educational institution as an object of public administration] Povyshenie kvalifikacii $i$ professional'noe sovershenstvovanie pedagogov: mezhdunar. nauch.-prakt. konf. - Proceedings from Professional development and professional improvement of teachers: Intern. scientific-practical Conf. (p. 156-161) Almaty [in Kazakhstan].

8. Moroz S. A., Moroz V. M., Dombrovskaya S. M. (2017). Rejting naukovopedagogichnih pracivnikiv, yak skladova sistemi derzhavnogo upravlinnya yakistyu vishoyi osviti [Rating of scientific and pedagogical workers as a component of the system of state quality management of higher education] Visnik NUCZU (Seriya "Derzhavne upravlinnya") - Bulletin of NUTZU (Series "Public Administration"), 2 (7), 294-309 [in Ukrainian].

9. Vazhinsky S. E., Scherbak T. I. (2016) Metodika ta organizaciya naukovih doslidzhen : navch. posib. [Methodology and organization of scientific research: teaching. Manual]. Sumi: SumDPU imeni A. S. Makarenka [in Ukrainian].

10. Moroz V. M., Sadkovij V. P., Babayev V. M., Moroz S. A. (2018). Onlajn opituvannya studentiv u sistemi zabezpechennya yakosti vishoyi osviti [Online Survey of Students in the System of Quality Assurance in Higher Education]. Informacijni tehnologiyi ta zasobi navchannya. - Information technologies and teaching aids, № 6, Retrieved from: https://journal.iitta.gov.ua/ index.php/itlt/article/view/2415 [in Ukrainian]. 
11. QS World University Rankings 2016 (2016). QS Top Universities. Retrieved from: https://www.topuniversities.com/university-rankings/worlduniversity-rankings/2016 [in USA].

12. QS World University Rankings 2019 (2019). QS Top Universities. Retrieved from: https://www.topuniversities.com/university-rankings/worlduniversity-rankings/2019 [in USA].

13. QS Higher Education System Strength Rankings 2018 (2018), Retrieved from: https://www.topuniversities. com/system-strength-rankings/2018 [in USA].

14. Sudman, S, Bradburn, N., \& Schwarz, N. (2010). Thinking About Answers: The Application of Cognitive Processes to Survey Methodology. San Francisco:Jossey-Bass [in USA].

15. Moroz S. A., Buka S. A., Buka I. S., Moroz V. M. (2018). Ocinyuvannya yakosti vishoyi osviti studentami yak element sistemi derzhavnogo kontrolyu za yakistyu nadannya osvitnih poslug zakladami vishoyi osviti (na prikladi opituvannya studentiv Baltijskoyi Mizhnarodnoyi Akademiyi, Latviya) [Assessment of the quality of higher education by students as an element of the system of state control over the quality of educational services provided by higher education institutions (for example, a survey of students from the Baltic International Academy, Latvia)] Visnik NUCZU (Seriya "Derzhavne upravlinnya") Bulletin of NUTZU (Series "Public Administration”), 2 (9), 282-295 [in Ukrainian].

\section{СПИСОК ВИКОРИСТАНИХ ДЖЕРЕЛ}

1. Гриневич Л. М. Пріоритетні напрями змін у вищій освіті на 2018-2019 pp. [Електронний ресурс] / Л. М. Гриневич // Міністерство освіти і науки України. Режим доступу: https:// mon.gov.ua/storage/app/media/ vishcha-osvita/infographik/MON prioritety_new.pdf

2. Lewis R. G. Total Quality in Higher Education. Total Quality Series / Lewis Ralph G., Smith Douglas H. Delray Beach: St Lucie Press, 1994. 330 p.

3. Barnett $R$. Improving Higher Education: Total Quality Care / Ronald Barnett. London: Open University Press, 1992. $240 \mathrm{p}$.

4. Owolia M. S. A framework for the dimensions of quality in higher education / Mohammad S. Owlia, Elaine M. Aspinwall // Quality Assurance in Education. 1996. Vol. 4, Iss. 2. P. 12-20.

5. Chua C. Perception of Quality in Higher Education [Electronic resource] / Clare Chua // AUQA Occasional Publication: Proceedings of the Australian Universities Quality Forum 2004. Access mode http://citeseerx.ist.psu. edu/viewdoc/download?doi=10.1.1.1 $25.3578 \&$ rep $=$ rep $1 \&$ type $=$ pdf

6. What Is Quality in Higher Education? / (Green Diana, William H. Stubbs, Baroness Pauline Perry and other); by ed. Green Diana. London: Society for Research into Higher Education \& Open University Press, 1994. 132 p.

7. Мороз C. A. Структура высшего учебного заведения как объект государственного управления / С. А. Мороз, В. М. Мороз // Повышение квалификации и профессиональное совершенствование педагогов: междунар. науч.-практ. конф., 26-27 ноября 2015 г. Алматы, 2015. С. $156-$ 161.

8. Мороз С. А. Рейтинг науково-педагогічних працівників, як складова системи державного управління якістю вищої освіти / С. А. Мороз, С. М. Домбровська, В. М. Мороз // Вісн. НУцЗУ (Серія “Державне управління”). 2017. Вип. 2 (7). C. 294-309. 
9. Важинський C. E. Методика та організація наукових досліджень: навч. посіб. / С. Е. Важинський, Т. І. Щербак. Суми: СумдПУ ім. А. С. Макаренка, 2016. 260 с.

10. Онлайн опитування студентів у системі забезпечення якості вищої освіти [Електронний ресурс] / В. М. Мороз, В. П. Садковий, В. М. Бабаєв, С. А. Мороз // Iнформаційні технології та засоби навчання. 2018. № 6. Режим доступу: https://journal.iitta.gov.ua/index. php/itlt/article/view/2415

11. QS World University Rankings 2016 [electronic resource] / Rankings // QS Top Universities. Access mode: https://www.topuniversities.com/ university-rankings/world-universityrankings $/ 2015$

12. QS World University Rankings 2019 [electronic resource] / Rankings // QS Top Universities. Access mode: https://www.topuniversities.com/ university-rankings/world-universityrankings/2019

13. QS Higher Education System Strength Rankings 2018, available at: https:// www.topuniversities.com/systemstrength-rankings/2018

14. Thinking About Answers: The Application of Cognitive Processes to Survey Methodology / S. Sudman, N. Bradburn, N. Schwarz. San Francisco: Jossey-Bass, 2010. 322 p.

15. Мороз С. А. Оцінювання якості вищої освіти студентами як елемент системи державного контролю за якістю надання освітніх послуг закладами вищої освіти (на прикладі опитування студентів Балтійської Міжнародної Академії, Латвія) / С. А. Мороз, І. С. Бука, С. А. Бука, В. М. Мороз // Вісн. НУЦЗУ (Серія “Державне управління”). 2018. Вип. 2 (9). С. 282-295. 